\author{
Asle Holthe \\ Avdeling for lcererutdanning, Høgskolen i Bergen \\ Oddrun Hallås \\ Avdeling for lcererutdanning, Høgskolen i Bergen \\ Eldbjørg T. Styve \\ Avdeling for lcererutdanning, Høgskolen i Bergen \\ Njål Vindenes \\ Avdeling for læererutdanning, Høgskolen i Bergen
}

\title{
Rammefaktorenes betydning for tilretteleggingen av opplæringen i de praktisk-estetiske fagene - en casestudie
}

\section{Sammendrag}

Kunnskapsløftet har til hensikt å bidra til at det gjennomføres systemendringer i grunnoppleringen. Formålet med denne artikkelen er derfor å undersøke hvordan ulike rammefaktorer påvirker skolens tilrettelegging av opplceringen $i$ de praktisk-estetiske fagene på 6. trinn. Studien er en sammenlignende casestudie. Data ble samlet inn på to barneskoler og inkluderer observasjoner, intervjuer og dokumenter.

Resultatene viser at spesielt skolens forståelse av det pedagogiske rammesystemet og hvordan skolen utnytter handlingsrommet knyttet til de administrative rammene og de ressursmessige rammene kan forklare hvordan den enkelte skole tilrettelegger opplaringen $i$ de praktisk-estetiske fagene. Resultatene viser også hvordan tilretteleggingen varierer mellom skolene. Videre viser funnene at de praktisk-estetiske fagene i liten grad er prioritert $i$ skolens implementering av Kunnskapsløftet. Artikkelen diskuterer også hvordan rammefaktorene påvirker kvaliteten i opplcringen i de praktisk-estetiske fagene.

Stikkord: implementering, rammefaktorer, kunst og håndverk, mat og helse, kroppsøving, musikk og praktisk-estetiske fag.

\section{Innledning}

De praktisk-estetiske fagene i grunnskolen er kunst og håndverk, mat og helse, kroppsøving og musikk, og fagenes omfang utgjør om lag en fjerdedel av grunnskolens samlede timetall. De ulike praktisk-estetiske fagene har grunnlag i kunstneriske, kulturelle og estetiske uttrykksformer og opplevelser (Halvorsen, 2008; Holthe, 2004; Kalsnes, 208; Segberg, 2008). Felles for disse fagene er 
altså at de i tillegg til å utvikle praktiske ferdigheter går inn i en teoretisk og historisk dannelsestradisjon hvor kombinasjonen av praktisk og teoretisk kunnskap utgjør fagenes egenart.

Utdanningsreformen Kunnskapsløftet har til hensikt å bidra til at det gjennomføres systemendringer i grunnopplæringen (Engelsen, 2008), og Hølleland (2007) hevder at denne reformen kan forstås som en struktur-, innholds- og styringsreform. Som strukturreform innebærer Kunnskapsløftet endringer i for eksempel fagenes navn, utdanningenes struktur og timetall, mens innholdsreformen kan knyttes til blant annet mål og innholdsendringer i læreplanverket. Styringsreformen dreier seg i stor grad om at det er gjort et tydeligere skille mellom politisk styring og fagpedagogisk styring. Politiske myndigheter fastsetter nasjonale mål, mens skolene får frihet til å velge metoder, definere innhold og velge virkemidler (Hølleland, 2007). Formålet med denne artikkelen er å undersøke hvordan ulike rammefaktorer påvirker skolens til rettelegging av opplæringen i de praktisk-estetiske fagene på 6. trinn.

\section{Teoretisk rammeverk}

Gjennom Kunnskapsløftet skulle skoleeiere og skoler få nye oppgaver og større frihet til å ta egne beslutninger om prioriteringer i opplæringen, tilpasset lokale forhold (Aasen \& Sandberg, 2010). Møller og kolleger (2010) hevder reformen derfor kan forstås som en myndiggjøring av lærere og skoleledere som profesjonsutøvere, samtidig som det forventes ansvarlighet. Profesjonsutøverne må svare for skolens resultater til skoleeier, foreldre og lokalsamfunnet for øvrig. Dette forutsetter at skolen har kapasitet til å fylle handlingsrommet med et reflektert planleggings-, vurderings- og utviklingsarbeid (Bachmann \& Bele, 2012).

Implementering av utdanningsreformer på skolenivå blir ofte omtalt som en organisatorisk endringsprosess som påvirker hva som skjer på det organisatoriske, sosiale og personlige plan (Fullan \& Stiegelbauer, 1991; Green \& Kreuter, 2005; Harris \& Lambert, 2003). I implementeringsforskning er kontekstualisering viktig fordi implementering av en spesifikk politikk knyttes til løsning av spesifikke utfordringer i samfunnet (Hill \& Hupe, 2002). Hvordan den enkelte skole tolker Kunnskapsløftet og de utfordringene denne reformen antas å skulle løse, kan påvirke implementeringsprosessen på den enkelte skole. Det dreier seg altså om at det ikke er en lineær sammenheng mellom politikkutforming og iverksetting, for eksempel ved at det er tvetydighet i reformen, motsetninger i reformen som ikke lar seg forene og mangel på ressurser og faglig kompetanse som ikke gjør implementering mulig (Aasen \& Sandberg, 2010; Karlsen, 2001).

Lundgren (1972, 1979) viste gjennom det som senere ble omtalt som rammefaktorteorien at samfunnets innvirkning på utdanningssystemet kom til uttrykk gjennom et målsystem, et administrativt system og et lovsystem. Engelsen (2012) hevder at mens Lundgren rettet oppmerksomheten mot de mer 
formelle rammene for skolen, har andre forskere bidratt med dokumentasjon av andre rammefaktorer som påvirker opplæringen. For eksempel viste Svingby (1978) at lærernes pedagogiske grunnsyn og praktiske undervisningsteori var sentrale rammefaktorer. Arfwedson \& Viken (1984) viste at lokale rammer som nærmiljøpåvirkning og skolens indre miljø påvirket opplæringen på den enkelte skole. Datnow (2002) hevder at et av de mest klare funnene fra forskning på utdanningsreformer siden 1960-tallet er betydningen av lokale forhold i implementeringsprosessen. Ut fra et implementeringsperspektiv vil rammefaktorer være uttrykk for lokale forhold ved den enkelte skole. I litteraturen grupperes rammefaktorene på ulike måter og i det videre arbeidet støtter vi oss til Imsen (2009) sin inndeling av rammefaktorer 1) Det pedagogiske rammesystemet, 2) De administrative rammene, 3) Ressursmessige rammer, 4) Organisasjonsmessige rammer og 5) Rammer knyttet til elevene og deres kulturbakgrunn.

Det pedagogiske rammesystemet dreier seg om skolens oppgave slik den er gitt i lov, forskrift og læreplanverk. Slike styringsdokumenter filtreres gjennom oppfatninger og tolkninger av lærere og av aktører i skolens lokalmiljø. De administrative rammene dreier seg om hvordan skolen ledes og struktureres, for eksempel organisering av dagen, klassestørrelse og samarbeid. Ressursmessige rammer omfatter økonomi og materielle ressurser som skolebygning, inventar og pedagogiske læremidler. Organisasjonsmessige rammer handler om de sosiale forholdene og den kulturen som råder på lærerværelset og ved skolen. På det nasjonale nivået skal politikere sørge for at skoleeierne har ressurser til å realisere den nasjonale skolepolitikken, mens politikere i kommunene har ansvar for å sørge for strategiske og økonomiske rammebetingelser og sikre at den nasjonale fellesskolen har god kvalitet (Møller et al., 2010). Rammer knyttet til elevene og deres kulturbakgrunn dreier seg om elevenes forutsetninger, deres skolemotivasjon og den støtte skolen får gjennom foreldresamarbeid og lokal kultur.

\section{Forskningsspørsmål/problemstilling}

Hvordan påvirker rammefaktorene skolens tilrettelegging av opplæringen i de praktisk-estetiske fagene på 6. trinn?

\section{Materiale og metode}

\section{Design og utvalgskriterier}

Det er gjennomført en sammenlignende casestudie (Yin, 2009). Ved utvelgelse av skoler ble det lagt vekt på at skolene skulle ha samme skoleeier og at det skulle være rene barneskoler. Videre var det et inklusjonskriterium at de skulle ha tilbud om de fire praktisk-estetiske fagene på 6. trinn. Endelig var det også en forutsetning at skolene skulle benytte seg av tilbudet i den kulturelle skole- 
sekken. De to første skolene som fylte disse kriteriene, og som sa seg villig til å delta i studien, inngikk i utvalget.

Studien er meldt til Personvernombudet for forskning. Alle informantene er gitt skriftlig informasjon om casestudien før intervjuene. De bekreftet muntlig under intervjuene at de ønsket å delta, og de ga sin tilslutning til at intervjuene kunne bli tatt opp elektronisk. Elever som deltok i studien og deres foreldre ga skriftlig samtykke til deltakelse.

\section{Presentasjon av casene}

Skole A ligger i utkanten av en kommune i Norge. Skolen er nylig oppusset. Det er 250-300 elever og 45-50 ansatte ved skolen. Skolen har egne spesialrom for alle de praktisk-estetiske fagene, lokaler som er tilpasset ulike læringsaktiviteter innenfor musikk og kunst og håndverk, gymnastikksal og et variert utemiljø tilpasset ulike læringsaktiviteter. Arealer for mat og helse er i lokaler som også brukes til kantine. Reisetid til kommunesenter er 20-25 minutter.

Skole B ligger sentralt i en kommune i Norge. Skolens bygningsmasse er fra 1970-tallet. Noe utvendig oppussing og videreutvikling av utearealer er foretatt. Det er 250-300 elever og 45-50 ansatte ved skolen. Det er ikke eget spesialrom til undervisning i musikk. Til kunst- og håndverksfaget har skolen eget rom til sløydundervisning. Det er egen gymnastikksal og et variert utemiljø tilpasset ulike læringsaktiviteter. Skolen har et eget spesialrom for mat- og helseundervisning. Reisetid til kommunesenteret er 5-10 minutter.

\section{Datakilder}

Dataene ble samlet inn gjennom observasjoner, intervjuer og dokumenter.

\section{Observasjoner}

Det ble utviklet et observasjonsskjema for å sikre at ensartet og systematisk informasjon ble samlet inn fra begge skolene. Observasjonsskjemaet var semistrukturert og inkluderte: (i) lokalisering, (ii) utsmykning av skolebygget, spesialrom for (iii) kunst og håndverk, (iv) mat og helse, (v) kroppsøving og (vi) musikk. For spesialrommenes del inkluderte observasjonene forhold som rommenes utforming og antall arbeidsplasser. Det ble foretatt pilottesting av observasjonsskjemaet før datainnsamlingen startet.

\section{Intervjuer}

På begge skolene ble det gjennomført individuelle intervjuer med rektor, fire lærere som hver underviste i henholdsvis kunst og håndverk, mat og helse, kroppsøving og i musikk. Det ble gjennomført ett fokusgruppeintervju med elever på hver skole. Det ble utviklet intervjuguider for å sikre at ensartet og systematisk informasjon ble innhentet. Intervjuguidene var semistrukturerte med åpne spørsmål knyttet til (i) mål og innhold, (ii) rammefaktorer, (iii) arbeidsmåter, (iv) elevforutsetninger og (v) vurdering. Intervjuguidene for 
intervju med rektorene fokuserte på de praktisk-estetiske fagene på skolenivået, mens intervjuguidene for intervjuene med lærerne fokuserte på lærernes erfaringer med det aktuelle faget. Intervjuguiden for intervjuer med elevene fokuserte på elevenes erfaringer med de fire praktisk-estetiske fagene. Det ble foretatt en pilottest av intervjuguidene før datainnsamlingen startet.

\section{Dokumenter}

Følgende dokumenter ble innhentet: timeplan for hvert av trinnene på skolen, ukeplan for 6. trinn en gitt uke, skolens virksomhetsplan og skolens lokale læreplan.

\section{Datainnsamlingen}

Datainnsamlingen ble foretatt av forfatterne i løpet av et dagsbesøk på hver av skolene i november 2011. Datainnsamlingen fulgte samme mønster på begge skolene: intervju med rektor, fokusgruppeintervju med elever, observasjoner på skolen og til slutt intervju med enkeltlærere.

Skolene valgte lærere og elever som skulle delta i intervjuene. Lærerne som deltok underviste i minst ett av praktisk-estetiske fagene på 6. trinn skoleåret 2011/12. Alle lærerne hadde lærerutdanning. Kunst- og håndverkslæreren på skole A hadde kunstfaglig utdanning, mens kunst- og håndverkslæreren på skole B ikke hadde fagfordypning i faget. Ingen av lærerne som underviste i mat og helse hadde fagfordypning i faget. Begge kroppsøvingslærerne hadde fagfordypning på 60 sp i faget. Musikklæreren på skole A hadde ikke fagfordypning, mens musikklæreren på skole $\mathrm{B}$ hadde $60 \mathrm{sp}$ i faget. Skolene satte sammen fokusgruppene med sju elever fra 6.trinn, slik at det var 3 eller 4 jenter, resten gutter.

\section{Analyse av data}

Alle intervjuene ble transkribert av forfatterne. Det ble valgt en caseorientert analyse (Yin, 2009) der materialet ble analysert med utgangspunkt i de ulike rammefaktorene. Først ble dataene kodet og gruppert innenfor de ulike rammefaktorene. Dataene ble så gruppert i underkategorier (Corbin \& Strauss, 2008). Deretter ble likheter og ulikheter innenfor det enkelte case og mellom casene undersøkt. Disse analysene ble diskutert av alle forfatterne for å være sikre på at dataenes innhold kom frem. Fordi dette er en kvalitativ studie er statistisk generalisering ikke mulig (Kvale, 2007). Analytisk generalisering skjedde gjennom triangulering ved å sammenligne observasjonsdataene, intervjuer og dokumenter. Data fra rektorer ble sammenholdt med data fra lærere og elever. 


\section{Resultater}

Basert på Imsen (2009) er resultatene presentert i følgende kategorier: 1) Det pedagogiske rammesystemet, 2) De administrative rammene, 3) Ressursmessige rammer, 4) Organisasjonsmessige rammer og 5) Rammer knyttet til elevene og deres kulturbakgrunn. For å anonymisere dataene er skolene nevnt som A og B, informantene er identifisert ved skole og ved R for rektor LKH for lærer i kunst og håndverk, LMH for lærer i mat og helse, LKR for lærer i kroppsøving, LMU for lærer i musikk og E for elev.

\section{1) Det pedagogiske rammesystemet}

Det pedagogiske rammesystemet er spesielt knyttet til læreplanene for fagene og opplæringsloven med forskrifter.

Kjennskapet til læreplanene i de praktisk-estetiske fagene varierer mellom skolene og informantene. Rektorene bruker i mindre grad begreper fra dagens læreplaner når de omtaler disse fagene, og de referer i liten grad til samtaler med personalet om fagenes innhold. På skolene tar heller ikke rektor, eller andre ledere ved skolen, direkte del i prosesser knyttet til prioritering og konkretisering av innholdet i de nasjonale læreplanene i disse fagene.

Begge rektorene påpeker at de får klare styringssignaler fra skoleeier på områdene lesing, realfag og digital kompetanse. Disse styringssignalene påvirker også skolens arbeid med konkretisering av læreplanene.
Vi får styringssignaler, vi får fagoppfølging. De praktisk-estetiske fagene etterspørres ikke. Vi blir etterspurt på fagene som er satsingsområder for skoleeier. Så det er der vi blir fulgt opp. Det er ingen som spør oss om vi har planer i de praktisk-estetiske fagene, og vi blir heller ikke bedt om å fortelle om eller å telle. Vi har konsentrert oss om planer etter K06 i de fagene skoleeier etterspør (B-R).

Samtlige lærere gir uttrykk for kjennskap til læreplanen i det faget de er intervjuet om, men har mindre faglig bevissthet om kompetansemålene i faget. Det er en tydelig oppfatning blant samtlige lærere at dette er praktiske fag, og at den dimensjonen er det meget viktig å opprettholde. Den praktiske dimensjonen oppfattes å være fagenes egenart, elevene får vist en annen side av seg selv enn de gjør i de øvrige fagene, og også fordi fagene fremstår som et avbrekk i en teoretisk skolehverdag.

Musikk er et praktisk fag, og kommer inn som et friskt pust i forhold til teorifagene. Det er noe som elevene tar veldig godt i mot. De ønsker det og de trenger det. Jeg tror at for alle elevene så er det kjærkomment med et avbrekk mellom matematikken, norsken og alle disse skrive-, lese- og sitte-rolig-fagene (B-LMU).

Men det fremkommer også betydelig variasjon i hvordan lærerne oppfatter fagets formål. For eksempel mener kroppsøvingslærer på skole A at det viktigste 
elevene skal lære i kroppsøvingsfaget er å følge regler, mens kroppsøvingslæreren på skole $\mathrm{B}$ mener det viktigste er at de opplever glede ved å være aktiv og tørre å være med på aktiviteter på eget nivå. Mat- og helselæreren på skole A oppfatter mat og kultur som fagets kjerneverdi, mens mat- og helselæreren på skole B fremhever kosthold og sunn mat som kjerneverdier.

Det er opp til den enkelte skole å velge lærestoff og prioritere i hvor stor grad de ulike elementene i læreplanen skal prioriteres. Ved skole A er det etablert lærergrupper innenfor fagene kroppsøving, kunst- og håndverk og musikk. På skole B er dette arbeidet overlatt til den eller de enkelte lærere i faget på trinnet. Ingen av skolene har lokale læreplaner i de praktisk-estetiske fagene. Skolene har i liten grad vektlagt sammenhengen mellom opplæringen i det enkelte fag fra 1.-4. trinn til 5.-7. trinn.

Med Kunnskapsløftet fikk skoleeier anledning til å omdisponere $25 \%$ av timene som er fastsatt i det enkelte fag for enkeltelever, når dette kan føre til bedre måloppnåelse $\mathrm{i}$ fagene for den enkelte elev samlet sett (Utdanningsdirektoratet, 2011). Ingen av skolene gir elever som kommer inn under $25 \%$-regelen styrking i de praktisk-estetiske fagene.

Nei, det er ikke mange elever. Det er et par elever. Men vi har ikke styrket de praktiskestetiske fagene. Det har vært mer sosial trening og da i samarbeid med kompetansemiljø innenfor atferd. De har noen opplegg på gården og sånne ting (B-R).

To elementer i regelverket for vurdering er utviklingssamtale/halvårsvurdering og foreldresamtale. Begge rektorene gir uttrykk for at de ikke har arbeidet spesielt mye med vurdering på skolen.

Både rektorer og lærere rapporterer at elevene får utviklingssamtale med kontaktlærer en gang hvert halvår og muntlig halvårsvurdering. Det varierer i hvor stor grad de praktisk-estetiske fagene inngår i utviklingssamtalen/halvårsvurderingen. Det synes å være mest vanlig å omtale elevenes kompetanse i de praktisk-estetiske fagene i samtalen dersom eleven som oppfattes som faglig svake i de øvrige fagene, men hvor han er bedre i de praktiskestetiske fagene. Dessuten er det mer vanlig å innlemme disse fagene i samtalene dersom kontaktlæreren underviser i faget.

Altså, vurdering er det jo. Vi har elevsamtaler og de får vurderinger i forhold hva de gjør, men jeg synes ikke vi har gjort det som et fellesskap, som en skole (A-R).

Begge skolene gjennomfører foreldresamtaler to ganger i året. Rektor på skole A forteller at foreldrene får tilbakemelding om elevens faglige utvikling i de praktisk-estetiske fagene på foreldrekonferanser. Rektor på skole B vet ikke om det gis slik tilbakemelding. 
Ja, for all del. Alle lærere skriver til kontaktlærer om hvordan eleven ligger an og kontaktlæreren tar det opp med foreldrene. Vi har veldig mye. Vi har elevsamtaler og utviklingssamtaler. Vi har skriftlighet og alt det der. Men vi har ikke gjort så mye i det siste (A-R).

Lærerne på begge skolene forteller derimot at elevens kompetanse i de praktiskestetiske fagene i liten grad tas opp under foreldresamtalene.

Jeg har ikke den kontakten med foreldrene, så det blir mer det som elevene gir uttrykk for overfor foreldrene, med mindre disse som har foreldrekontakten og elevkontakten gjør det. Men der kunne det sikkert vært gjort en bedre jobb. Jeg gjør jo omtrent ingenting med det da (A-LKH).

Noen ganger informer jeg, og særlig med elever som ikke strekker til i andre fag (B-LKR).

\section{2) De administrative rammene}

De administrative rammene er spesielt knyttet til organisering av dagen, klassestørrelse og samarbeid.

Minstetimetallet i grunnskolen er fastsatt nasjonalt. Det er opp til skoleeier å fastsette hvordan timene skal tas ut. Begge skolene har fast organisering av skoledagen gjennom hele året. Ingen av skolene praktiserer periodeplaner. Basert på timeplaner og intervjuer med lærere og elever viser tabell 1 den samlete tiden elevene på 6. trinn var på skolen en ordinær uke, mens tabell 2 viser omfanget av praktisk estetiske fag på dette trinnet. 
Tabell 1: Oversikt over skoleukens varighet, 6. trinn. Tid til den enkelte elev (min).

\begin{tabular}{lll}
\hline & Skole A & Skole B \\
\hline Skoleukens varighet & 1525 & 1610 \\
Fysisk aktivitet & 30 & 40 \\
Friminutt & 195 & 330 \\
Spisetid & 75 & Inngår i undervisningstiden \\
Undervisningstid & 1225 & 1245 (inkl. matpause) \\
Timeplanlagt tid til praktisk- & & \\
estetiske fag & 350 & 390 \\
Timeplanlagt tid til andre fag & 875 & 845 \\
\hline
\end{tabular}

Tabell 2: $\quad$ Timeplanlagt tid til de praktisk-estetiske fagene pr. uke, 6. trinn. Tid til den enkelte elev (min)

\begin{tabular}{lll}
\hline & Skole A & Skole B \\
\hline Timeplanlagt tid kunst og håndverk & $60 / 200(1)$ & 60 \\
Timeplanlagt tid mat og helse & $0 / 140(1)$ & 105 \\
Timeplanlagt tid kroppsøving & 75 & 120 \\
Timeplanlagt tid musikk & 75 & 105 \\
\hline
\end{tabular}

(1) Fagene mat og helse og kunst og håndverk er timeplanteknisk koordinert slik at hver elev får 4 økter mat og helse hver høst og 4 økter mat og helse hver vår. Disse 4 ukene har elevene 140 min mat og helse hver uke. Alle elevene har 60 min kunst og håndverk hver uke. De ukene elevene ikke har mat og helse, får elevene 200 min kunst og håndverk

Begge skolene har organisert lærerne på 6. trinn i ett team. Det fremgår av intervjuene at ledelsen på begge skolene har gitt teamene betydelig frihet til å bestemme hvilke fag som skal tilbys og i hvilket omfang.

Av tradisjon har det på skolen alltid vært 6. trinn som har mat og helse. Og når de la timeplanen i høst, så vi at vi hadde en kunst- og håndverkslærer som var inne om tirsdagen i klassen, og de to andre kontaktlærerne har også kunst og håndverk. Da så vi på dette, og var enige om å satse på disse fagene og ha en firedeling av klassen. Da er vi fire lærere i disse klassene, så vi legger inn mye ressurser i disse fagene (A$\mathrm{LMH})$.

På skole A får den enkelte elev i underkant av 19 timer undervisning i mat og helse på 6. trinn. Rektor oppgir at hovedtyngden av opplæringen i dette faget er lagt til 6. trinn. Faget er ikke timeplanlagt på andre trinn på denne skolen, men inngår i noen tverrfaglige prosjekter. Det fremstår som om beslutninger i lærerteamet som har ført til styrkning av kunst og håndverk, går på bekostning av ett eller flere at de andre praktisk-estetiske fagene på denne skolen.

Det varierer hvordan timene til de praktisk-estetiske fagene er organisert. Timene i mat og helse er organisert i blokk på begge skolene. Timene i kroppsøving, musikk og kunst og håndverk er organisert i blokk på skole $\mathrm{A}$, men som enkelttimer på skole B. På skole A er de praktisk-estetiske fagene timeplanlagt etter lunsj og elevene har praktisk-estetiske fag fem dager i uken. På skole B er 
timene i de praktisk-estetiske fagene lagt etter lunsj, og elevene har praktiskestetiske fag fire dager i uken. Elever har synspunkter på organiseringen.

Mat- og helsetimene kunne vart litt lenger. Det er liksom litt mer du kan lage hvis det varer litt lenger. Du kan ikke lage så mye på den tiden, du må liksom beregne tiden (A-E8).

Jeg synes vi burde fått litt lengre tid i kunst og håndverk. For noen ganger hvis vi skal prøve å lage det veldig fint, og bruke litt tid på det, så får man ikke tid. Og så neste gang er det noe nytt (B-E6).

Gruppestørrelsen i de praktisk-estetiske fagene varierer mellom skolene og mellom fagene slik det fremgår av tabell 3.

Tabell 3: Gruppestørrelse i de praktisk-estetiske fagene.

(Basert på skolenes timeplan og lærerintervjuer)

\begin{tabular}{lll}
\hline & Skole A & Skole B \\
\hline Antall elever på 6. trinn & 41 & 36 \\
Kunst og håndverk & $10-11$ & 12 \\
Mat og helse & $10-11$ & $17-19$ \\
Kroppsøving & $20-21$ & $17-19$ \\
Musikk & $20-21$ & $17-19$ \\
\hline
\end{tabular}

Gruppestørrelsen i kunst og håndverk omtales av lærerne i faget som svært positiv, lærerne får mer tid til oppfølging av den enkelte elev. De andre lærerne har ikke merknader til gruppestørrelsen, med unntak av mat og helselæreren på skole B som opplever at 19 elever på undervisningskjøkkenet er for mange, rommet er ikke dimensjonert til så mange elever.

På begge skolene foregår det noe tverrfaglig samarbeid, i hovedsak når lærere i praktisk-estetiske fag også har andre fag i den aktuelle klassen. Det kan være felles tema i naturfag og kroppsøving (uteaktiviteter), kroppsøving og samfunnsfag (sykkeldag) og naturfag og mat og helse (kropp, ernæring og helse), kunst og håndverk og RLE (kunst i religion). Ved skole A er det også tradisjon for et show-prosjekt på 7. trinn som involverer flere av de praktiskestetiske fagene.

\section{3) Ressursmessige rammer}

Ressursmessige rammer omfatter økonomi og materielle ressurser som skolebygning, inventar og pedagogiske læremidler.

Det fremgår både av intervju med rektorene og lærerne at de økonomiske ressursene på skolene oppleves som begrenset. Det synes som om skolene har en svært bevisst og streng prioritering når det gjelder kjøp av utstyr.

Rammene for innkjøp er dårlig. Den er som ved alle andre skoler. Vi har et lite driftsbudsjett for å gjøre noe som helst (A-R). 
Vi hadde besøk av en kunstner i kunst- og håndverkstimene. Vi skulle trekke et dikt, så skulle vi tegne til diktet og lage et metallbilde. Det ble avbrutt fordi kommunen ikke hadde nok penger til å betale kunstneren. Vi har ikke fått gjort det ferdig, det var litt dumt (A-E1).

Lærerne rapporterer ikke at de økonomiske rammene for forbruksmateriell i de praktisk-estetiske fagene er en begrensning for opplæringen i fagene.

Jeg har ikke fått noen konkret sum jeg kan bruke til innkjøp av mat. Men jeg fikk en muntlig avtale med rektor. Bruk penger med måte. Så jeg handler inn det vi trenger (B-LMH).

Informantene vektlegger at praktisk arbeid er helt sentralt i de praktisk-estetiske fagene. Observasjonsdataene viste at tilgangen til spesialrom varierte betydelig mellom de to skolene, slik det fremgår av tabell 4 .

Tabell 4: Oversikt over spesialrom til praktiske-estetiske fag i skolebygget.

\begin{tabular}{lll}
\hline & Skole A & Skole B \\
\hline Kunst og håndverk - & Undervisningsrom for leire & Keramikkrom* \\
spesialrom & Undervisningsrom for & \\
& tøymaterialer & \\
& Undervisningsrom for sløyd & Undervisningsrom for sløyd \\
& Undervisningsrom for maling & \\
& Undervisningsrom for & \\
& tegning &
\end{tabular}

Mat og helse - spesialrom

Undervisningskjøkken med grovkjøkken (15-20 arbeidsplasser)

Spiseplass i skolens kantine Egen kjøkkenkrok i basene

Kroppsøving - spesialrom

Musikk - spesialrom
Gymsal med garderober og lager
Kultursal med scene
Undervisningskjøkken (16 arbeidsplasser)

Spiseplass på kjøkken

Gymsal med garderober og lager

Dramarom

$\varnothing$ vingsrom for dans

\footnotetext{
* Brukes som lager
}

Spesialrommene var godt integrert i skolenes bygg og begge skolene har godt tilrettelagt utemiljø. Skole A hadde langt bedre fasiliteter enn skole B. På skole $\mathrm{B}$ var musikkrommet og kunst og håndverksrommet som var beregnet på myke materialer omgjort til ordinære klasserom. På denne skolen foregikk derfor 
opplæringen i disse fagene i stor grad i vanlige klasserom og i felles areal. Lærerne rapporterte at dette ga klare begrensninger for opplæringen i disse fagene.

Vi har ikke noe egnet rom. Vi bærer instrumentene rundt, vi spiller i fellesarealet i hjertet av skolen der klasserommene ligger rundt. Jeg skulle ønske at vi fikk et musikkrom igjen. Det å musisere på elevenes arena, med slagverk og bassgitar, er ikke lett her hos oss (B-LMU).

På denne skolen etterspurte også elevene mer praktisk opplæring i musikkfaget.

De pedagogiske læremidlene som lærebøker, pedagogisk programvare og ressursbøker relevant for de praktisk-etiske fagene er begrenset på skolene. Det er bare i musikk på skole A det er tilgang til lærebøker. I mat og helse brukes skriftlig materiell utviklet av opplysningskontorene. I musikk er det tilgang til pedagogisk programvare på begge skolene. Lærerne opplyser at det er lite nyere faglitteratur på skolebiblioteket og i ressurssamlingene for lærerne. Med unntak av musikk på skole A synes det som om lærerne i stor grad utvikler sine egne læremidler basert på ulike kilder.

Jeg henter gjerne ned ting fra nettet, tar bilder av bøker og lager presentasjoner sånn at elevene ikke begynner på bar bakke, men får en forståelse av hva jeg er ute etter. At jeg løfter dem litt, sånn at jeg kan gi dem tanker og ideer. Så selv om vi ikke har hatt bøker, så har vi hatt dette materiellet (A-LKH).

\section{4) Organisasjonsmessige rammer}

Organisasjonsmessige rammer handler om de sosiale forholdene og den kulturen som råder ved skolen.

På begge skolene er lærerne organisert i team som i hovedsak dekker opplæringen innenfor trinn, og teamene har en betydelig påvirkning på organisering og gjennomføring av opplæringen. I de praktisk-estetiske fagene synes det å være en felles planlagt undervisning, enten ved at det bare er en lærer som har ansvar for all undervisning i et fag, eller ved at flere lærere samarbeider og utvikler felles undervisningsopplegg. Undervisningen er i stor grad organisert slik at en lærer har ansvar for en gruppe.

Både rektorer og lærere forteller at det er en positiv holdning til de praktiskestetiske fagene på de to skolene. Dette forklares dels ved at rektorene er opptatt av disse fagene, at mange lærere underviser i fagene, at fagene fremstår som et positivt avbrekk for elevene, og opplæringen i fagene resulterer ofte i fremføringer og presentasjoner som oppleves som positive og skapende i skolemiljøet. Samtidig fremhever både rektorer og lærere at de praktisk-estetiske fagene ikke oppfattes som like viktige som enkelte av de andre fagene på slutten av barnetrinnet. 


\section{5) Rammer knyttet til elevene og deres kulturbakgrunn}

Rammer knyttet til elevene og deres kulturbakgrunn dreier seg om elevenes forutsetninger, deres skolemotivasjon og den støtte skolen får gjennom foreldresamarbeid og lokal kultur.

Samtlige rektorer og lærere er samstemte i at elevene er motivert for de praktisk-estetiske fagene

Det er liksom ingen negative kommentarer. For det er veldig lett at det kommer hos de fleste. Det er ingen som stikker av eller gjemmer seg under bordet. De er der og bidrar. Den dialogen de har seg i mellom. De klarer å vente på tur og fordele oppgaver. De har en veldig stor kompetanse i forhold til det sosiale i faget. Ikke i alle fag, men her ser man at de har lyst (A-R).

Lærerne rapporterer at elevene jevnt over har gode forutsetninger for opplæringen i de praktisk-estetiske fagene, selv om lærerne også forteller at elevforutsetningene varierer i disse fagene.

Skole A har noen elever med fremmedkulturell bakgrunn. Rektor og lærerne i kunst og håndverk og mat og helse forteller at de trekker inn disse elevenes kulturbakgrunn i undervisningen. Ved skole B er det ikke elever med fremmedkulturell bakgrunn, og lærerne forteller at de heller ikke arbeider med det flerkulturelle i undervisningen.

I fjor da vi jobbet med linosnitt, tok jeg hensyn til at vi hadde en afrikansk jente i

klassen. Da tok vi utgangspunkt i afrikanske masker og lot det være motiv for linosnitt. Og det hadde stor suksess (A-LKH).

Elevene har ulike oppfatninger av hvilke fag de liker. På begge skolene er det elever som liker best kunst- og håndverk eller kroppsøving, på skole A liker noen best mat og helse. Ingen av elevene nevner de praktisk-estetiske fagene som fag de ikke liker. Det synes å være en klar oppfatning blant elevene på begge skolene at de viktige fagene er norsk, matematikk og engelsk.

Engelsk, matematikk og norsk, det er egentlig de tre viktigste fagene, mener jeg, fordi de er de grunnfagene du bør være god i. De andre fagene kommer litt utenom (A-E8).

Samarbeid med foreldrene skjer i hovedsak gjennom foreldreutvalget på skolene, foreldremøter, foreldrekonferanser og ved at foreldre inviteres til elevfremføringer på skolene. Rektorer og lærere forteller at foreldrene viser stor oppslutning på forestillinger hvor elevene har fremføringer, og dette oppleves som positivt og inspirerende for elevene og personalet.

Samarbeid med eksterne kompetansemiljø som involverer de praktiskestetiske fagene, er avgrenset til kontakt med kunstnermiljø og andre fagmiljø i kunst og håndverk ved skole $\mathrm{A}$, og kontakt med fagmiljøer relevant for musikk ved begge skolene. Ellers har begge skolene god kontakt med frivillige organisasjoner som skolekorps, idrettslag og speidergrupper. Gjennom dette samarbeidet 
forgår det en del byttelån av utstyr, men ingen av de eksterne organisasjonene trekkes aktivt inn i undervisningen.

\section{Diskusjon og konklusjon}

Innledningsvis i denne artikkelen ble Kunnskapsløftet omtalt som en struktur-, innholds- og styringsreform. Våre funn indikerer at skolene i større grad har implementert elementer som kan knyttes til struktur- og styringsreformen enn til reformens innholdselementer. Tidligere implementeringsforskning har vist at egenskaper ved selve reformen har betydning for om den blir implementert (Rogers, 2003). For eksempel vil elementer som er synlige og oppfattes som enkle i forhold til eksisterende praksis, lettere bli implementert enn elementer som oppfattes som komplekse. Strukturreformene for barnetrinnet, som endringer i navn og timetall, har vært synlige og er enkle, og dette kan forklare hvorfor skolene i stor grad har klart å implementere disse elementene. Haug (2003) påpeker at det fra 1980-tallet har foregått en betydelig desentralisering og omorganisering av kommunene, som igjen har ført til styringsendringer i skoleverket. At det har pågått styringsendringer i skoleverket over lang tid kan ha bidratt til at skolene har prioritert styringsendringer som for eksempel at lærerne på caseskolene er organisert $\mathrm{i}$ team for hvert trinn, og at disse har fått større frihet til å organisere undervisningen og fordele oppgaver på trinnet. Styringsreformen gir rom for en myndiggjøring av lærere og skoleledere som profesjonsutøvere (Møller et al., 2010). Resultatene viser at rektorene og lærerne i de praktisk-estetiske fagene ikke fremstår som mer myndiggjorte med en klar bevissthet om kompetansemål, læringsmål, læringsaktiviteter og vurderingskriterier. På andre områder som fag- og timefordeling og gruppestørrelser fremstår rektorene og lærerne som mer myndiggjorte. Myndiggjøring kan også knyttes til ansvarlighet og ansvarliggjøring (Møller et al., 2010), at de må svare for prioriteringer og skolens resultater overfor skoleeiere, foreldre og lokalsamfunn. Funnene viser at skoleledere og lærere har et sterkt fokus på skoleeiers prioriteringer, og de blir dermed ansvarliggjort på disse feltene ved at skoleeier stiller resultat- og rapporteringskrav. Derimot synes rektorene og lærerne å være langt mindre ansvarliggjort for om elevene får det forskriftbestemte timetallet i de praktisk-estetiske fagene, om innholdet i halvårssamtalene og foreldresamtalene er i tråd med forskriftene og om elevenes læringsutbytte i disse fagene. Dette kan trolig knyttes til at skolens prioriteringer på disse områdene er lite transparente, og at skoleeier og nasjonale skolemyndigheter i liten grad har satt rapporteringskrav innenfor disse områdene. Når skolene i mindre grad synes å ha implementert innholdselementer fra reformen, kan det skyldes at de oppfattes som komplekse og mindre forenlig med eksisterende praksis (Rogers, 2003), og at lærernes undervisningspraksis i stor grad preges av stabilitet (Datnow, 2002; Klette, 
2003). Når skolene i liten grad har drevet utviklingsarbeid knyttet til de praktiskestiske fagene, kan dette også forstås innenfor en nasjonal utdanningsmessig kontekst der de praktisk-estetiske fagene har fått en svekket posisjon (Espeland, Allern, Carlsen, \& Kalsnes, 2011; Ommundsen, 2013), og at skolene tilpasser seg reformen innenfor en slik forståelse.

Tidligere implementeringsforskning viser at nasjonale utdanningsreformer som implementeres fra sentralt forvaltningsnivå, ofte får problemer når de møter det lokale forvaltningsnivået, den enkelte skole og den enkelte lærer (Datnow, 2002; Hargreaves \& Fink, 2000), og at blant annet gode forbindelseslinjer mellom styringsnivåene er avgjørende for en vellykket reformimplementering (Datnow, 2002). Resultatene viser at skoleeier for skole A og B har gjort prioriteringer som følges opp på den enkelte skole. På begge skolene vektlegges arbeid med de satsingsområder (lesing, realfag og IKT) skoleeier har prioritert og etterspurt. Innenfor disse satsingsområdene synes det å være etablert en god dialog mellom skoleeier og skole som sikrer felles forståelse, tilslutning og tydeliggjøring av ansvar og roller. Skoleeierens rolle på dette feltet kan forstås som tiltak for å skape bedre forbindelseslinjer mellom sentralnivået og den enkelte skole, og innebærer en desentralisering av beslutningsmyndighet (Bachmann \& Bele, 2012). Funnene viser at lesing, realfag og IKT i liten grad inngår som sentrale innholdselementer i de praktisk-estetiske fagene. Dette kan indikere at skolene i liten grad oppfatter de praktisk-estetiske fagene som relevante for å styrke elevenes kompetanse innenfor satsingsområdene. Dette kan bidra til å svekke disse fagenes posisjon ytterligere fordi de ikke oppfattes å inngå i det lokale forvaltningsnivåets prioriteringer.

Forhold ved den enkelte skole har betydning for implementeringsprosessen på skolenivå (Datnow, 2002; Fullan, 1999) og knyttes ofte til endringer på det organisatoriske, sosiale og personlige plan (Green \& Kreuter, 2005). Våre data viser at det pedagogiske rammesystemet i stor grad blir forstått ut i fra tidligere praksis på skolene. Tilsvarende funn er gjort i evalueringen av L97, der en blant annet fant at endring i læreplanene for kroppsøving og kunst og håndverk i liten grad hadde fått praktisk gjennomslag i undervisningen (Jacobsen \& Moser, 2005; Kjosavik, 2004). Videre viser våre funn at det er liten sammenheng i opplæringen i fagene mellom 1.-4. trinn og 5.-7. trinn, og skolene har i begrenset grad tilpasset seg det nye regelverket for elevvurdering. Det synes derfor som om skolene i liten grad har satt i gang tiltak som kan bidra til endring på skolenivå med sikte på å implementere innholdselementene i de praktisk-estetiske fagene. Unntaket er skole A hvor en nå har etablert lærergrupper innenfor de fleste praktisk-estetiske fagene. Sett i et implementeringsperspektiv vil slike plangrupper kunne påvirke både personlige faktorer som kunnskaper og holdninger, og sosiale faktorer som sosial støtte fra kolleger og ledere (Green \& Kreuter, 2005; Miller \& Shinn, 2005) og slik styrke implementeringen. De administrative rammene varierer i betydelig grad på skolene. Det dreier seg i særlig grad om hvordan skolene har organisert skoledagens lengde, friminutt, 
spisetid, gruppestørrelse og timeplanlegging av fagene. Klette (2003) har i en tidligere studie rapportert betydelige variasjoner mellom skoler når det gjelder organisering av skoledagen, og hun fant blant annet at skoledagen på barnetrinnet gjennomgående var organisert i fleksible arbeidsøkter der en tok pause etter behov, men med felles spisepause for hele skolen midt på dagen. De administrative rammene kan ses på som endring i organisatoriske faktorer (Green \& Kreuter, 2005) som kan motivere eller være barrierer for implementeringsprosessen. For eksempel viser våre funn at gruppestørrelsen i kunst og håndverk ble oppfattet som positiv av lærerne på begge skolene, mens gruppestørrelsen i mat og helse på skole $\mathrm{B}$ ble oppfattet som en begrensning for opplæringen i faget. De ressursmessige rammene varierer mellom de to skolene. Dels dreier dette seg om tilgang på spesialrom og pedagogiske læremidler. Jensen (2008) hevder at lærere på barnetrinnet i liten grad er berørt av nye kunnskapskrav og læringsprosesser, og at lærerne i liten grad bruker kunnskapsressurser som er spesifikke for egen profesjon. Våre funn støtter dette ved at lærerne i liten grad omtaler behov for kunnskapsressurser og i stor grad tilpasser mangel på læremidler ved å hente materiell fra åpne og allmenne kilder. Mangel på spesialrom i musikk og kunst og håndverk på skole B fremstår som en begrensende faktor for implementeringen av læreplanen i disse fagene.

Svingby (1978) påpeker at både de formelle rammene for skolens virksomhet og de uformelle faktorene i personalet påvirker skolens arbeid. De formelle rammene regulerer skolens ytre struktur og maktstrukturen. De uformelle rammene dreier seg om lærernes oppfatninger av de muligheter de formelle rammene gir, og hvordan disse kan forstås innenfor skolens tradisjon og lærerens pedagogiske grunnsyn. De formelle rammene, som for eksempel læreplanene, gir skolen et handlingsrom som ikke er entydig og klart avgrenset. Hvordan skolen fyller handlingsrommet vil i følge Singby (1978) avgjøres av de uformelle faktorene. Når de to mat- og helselærerne og de to kroppsøvingslærerne har ulike oppfatninger om formålet i læreplanene for henholdsvis kroppsøving og mat og helse, kan dette være uttrykk for den enkelte lærers pedagogiske grunnsyn. Lærerens autonomi i klasserommet gjør at lærerens grunnsyn i stor grad blir styrende for undervisningen (Svingby, 1978). Ledelsen på case skolene involverte seg lite i arbeidet med å konkretisere læreplanene og det var heller ikke utviklet lokale læreplaner. På skole B var dette arbeidet overlatt til den enkelte lærer, mens det på skole A var opprettet lærergrupper i fagene. Når dette arbeidet i all hovedsak er overlatt til den enkelte lærer, vil trolig den enkelte lærers pedagogiske grunnsyn bli mer styrende for opplæringen enn om læreren tar aktivt del i et fortolkningsfellesskap der det er ulike fagdidaktiske oppfatninger.

Hvordan skolene implementerer Kunnskapsløftet vil kunne påvirke opplæringens kvalitet (Haug, 2012). På skole B har elevene betydelig mer tid til både organisert fysisk aktivitet og friminutt. Ut fra tidligere forskning er det rimelig å anta at økt fysisk aktivitet i skolehverdagen skaper større variasjon i 
skolehverdagen og øker motivasjonen for læring (Trudeau \& Shephard, 2008) og vil dermed kunne styrke både struktur- og prosesskvaliteten. Ved skole B tas spisetiden fra undervisningstiden, mens spisetiden kommer i tillegg til undervisningstiden på skole A. På skole A har en styrket timetallet i kunst og håndverk på bekostning av timetallet i mat og helse. Tidligere forskning har vist at timetallet har positiv effekt på elevenes faglige resultater (Opheim, Grøgaard, \& Næss, 2010; Wiborg, 2011), og skoler med relativt høyt timetall har høyere gjennomsnittlige skoleprestasjoner enn skoler med relativt lave timetall (Opheim et al., 2010). Selv om disse studiene først og fremst er knyttet til de nasjonale prøvene, er det rimelig å anta at redusert undervisningstid $\mathrm{i}$ et fag påvirker strukturkvaliteten negativt, mens et økt timetall påvirker strukturkvaliteten positivt. Timetallet i et fag vil også kunne påvirke den metodiske tilnærmingen og dermed også prosesskvaliteten. De ressursmessige rammene som er knyttet til mangel på spesialrom, antas å påvirke strukturkvaliteten negativt på skole $\mathrm{B}$ fordi mangel på spesialrom i stor grad begrenser læringsaktivitetene i musikk og kunst og håndverk. Mangel på pedagogiske læremidler kan begrense strukturkvaliteten ved at undervisningen i stor grad blir avhengig av lærene. Samtidig vil plansystem, lærersamarbeid og høy fag- og fagdidaktisk kompetanse blant lærerne kunne kompensere for manglende læremidler.

Denne studien har noen styrker og svakheter som det må tas hensyn til når dataene tolkes. En styrke ved studien er at det er brukt flere datakilder og ulike grupper informanter. Det er også en styrke at dataene er samlet inn og tolket av en gruppe forskere med fagkompetanse i de fire praktisk-estetiske fagene. En svakhet ved studien er at få skoler inngår i materialet. Selv om funnene ikke gir et generelt bilde av opplæringen i de praktisk-estetiske fagene på barnetrinnet, bidrar studien med kunnskap om et felt som er lite utforsket.

Selv om studien bare er basert på data fra to skoler mener vi noen implikasjoner kan skisseres. For skolene synes det å være viktig å fokusere på innholdselementene i reformen gjennom et systematisk organisatorisk arbeid knyttet til de praktisk-estetiske fagene. Skoleeiere og nasjonale skoleeiere bør vurdere å innføre kontroll med at elevene får det faktiske timetallet i de ulike fagene og det bør klargjøres om spisetiden skal inngå i undervisningstiden. Skriftlig vurdering i alle fag på barnetrinnet vil trolig kunne bidra til et styrket fokus på læringsutbyttet i de praktisk-estetiske fagene.

\section{Referanser}

Aasen, P., \& Sandberg, N. (2010). Hvem vet best? Om styringen av grunnopplæringen under Kunnskapsløftet. Acta Didactica Norge. (Vol. 4). http://journals.ils.uio.no/index.php/adno/article/view/158/172

Arfwedson, G., \& Viken, E. (1984). Hvorfor er skoler forskjellige? Oslo: Tanum-Norli.

Bachmann, K. E., \& Bele, I. (2012). Rammer og prioriteringer i skolens kvalitetsarbeid. I P.

Haug (Red.), Kvalitet i opplæringa: arbeid i grunnskulen observert og vurdert (s. 33-57).

Oslo: Samlaget. 
Corbin, J. M., \& Strauss, A. L. (2008). Basics of qualitative research: techniques and procedures for developing grounded theory. Thousand Oaks, California: Sage.

Datnow, A. (2002). Can We Transplant Educational Reform, and Does It Last? Journal of Educational Change, 3(3), 215-239. doi: 10.1023/a:1021221627854 http://link.springer.com/content/pdf/10.1023\%2FA\%3A1021221627854.pdf

Engelsen, B. U. (2008). Kunnskapsløftet. Sentrale styringssignaler og lokale strategidokumenter. Oslo: Universitetet i Oslo.

Engelsen, B. U. (2012). Kan læring planlegges?: arbeid med læreplaner - hva, hvordan, hvorfor. Oslo: Gyldendal akademisk.

Espeland, M., Allern, T.-H., Carlsen, K., \& Kalsnes, S. (2011). Praktiske og estetisk fag og læererutdanning. Rapport nr. 1. Stord: Høgskolen Stord/Haugesund. http://brage.bibsys.no/hsh/bitstream/URN:NBN:no-bibsys brage_16239/1/Rapport.pdf

Fullan, M. (1999). Change forces. London: Falmer.

Fullan, M., \& Stiegelbauer, S. ( 1991). The new meaning of educational change. London: Cassell.

Green, L. W., \& Kreuter, M. W. ( 2005). Health program planning: an educational and ecological approach. New York: McGraw-Hill.

Halvorsen, E. M. (2008). Fagdidaktikk i kunst og håndverk. I E. M. Halvorsen (Red.), Didaktikk for grunnskolen (s.206-235). Bergen: Fagbokforlaget.

Hargreaves, A., \& Fink, D. (2000). The Three Dimensions of Reform. Educational Leadership, 57(7), 30-33.

Harris, A., \& Lambert, L. ( 2003). Building leadership capacity for school improvement. Maidenhead: Open University Press.

Haug, P. (2003). Evaluering av Reform 97. Oslo: Norges forskningsråd.

Haug, P. (2012). Kvalitet i opplæringa. I P. Haug (Red.), Kvalitet i opplæringa. Arbeid i grunnskulen observert og vurdert (s. 9-32). Oslo: Samlaget.

Hill, M. J., \& Hupe, P. L. (2002). Implementing public policy: governance in theory and practice. London: Sage.

Holthe, A. (2004). Måltidet som konstruksjon i heimkunnskapsfaget. I G. O. Hole \& T. T. T. Sudmann (Red.), Vitenskapsteoretiske refleksjoner Essaysamlng (s. 251-273). Bergen: Høgskolen i Bergen. https://bora.hib.no/bitstream/10049/127/1/holtheessay.pdf

Hølleland, H. (2007). Innføring i kunnkskapsløftet. I H. Hølleland (Red), På vei mot Kunnskapsløftet: begrunnelser, løsninger og utfordringer. Oslo: Cappelen akademiske forlag.

Imsen, G. (2009). Lererens verden: innføring i generell didaktikk. Oslo: Universitetsforlaget.

Jacobsen, E. B., \& Moser, T. (2005). L97 og kroppsøvingsfaget med fokus på ungdomstrinnet. Norsk pedagogisk tidsskrift.Vol. 89 nr 3. s.244-260.

Jensen, K. (2008). ProLearn:Profesjonslæring i endring. Oslo: Forskningsrådet.

Kalsnes, S. (2008). Fagdidaktikk i musikk. I E. M. Halvorsen (Red.), Didaktikk for grunnskolen (s.236-261). Bergen: Fagbokforlaget.

Karlsen, G. E. (2001). Implementering av utdanningsreformer. I S. S. Hovdenak (Red.), Perspektiver på Reform 97 (s. 19-37). Oslo: Gyldendal akademisk.

Kjosavik, S. (2004). Kunst og håndverk - et nytt fag, men ble det nytt? I K. Klette (Red.), Fag og areidsmåter i endring? : tidsbilder frå norsk grunnskole (s. 157-169). Oslo: Universitetsforlaget.

Klette, K. (2003). Klasserommets praksisformer etter Reform 97. Oslo: Pedagogisk forskningsinstitutt. http://folk.uio.no/khflyum/arkiv/Reform97-Rapport-1-03.pdf

Kvale, S. ( 2007). Inter Views: an introduction to qualitative research interviewing. London: Sage Publications. 
Lundgren, U. P. (1972). Frame factors and the teaching process: a contribution to curriculum theory and theory of teaching. Stockholm.

Lundgren, U. P. (1979). Att organisera omværlden: en introduksjon til læroplansteori. Stockholm: liberFørlag.

Miller, R. L., \& Shinn, M. (2005). Learning from communities: Overcoming difficulties in dissemination of prevention and promotion efforts. American Journal of Community Psychology, 35(3-4), 169-183. doi: 10.1007/s10464-005-3395-1 http://link.springer.com/article/10.1007\%2Fs10464-005-3395-1?LI=true\#page-1

Møller, J., Ottesen, E., \& Hertzberg, F. (2010). Møtet mellom skolens profesjonsforståelse og Kunnskapsløftet som styringsreform. Acta Didactica Norge, Vol 4, Nr. 1: http://adno.no/index.php/adno/article/view/140

Ommundsen, Y. (2013). Fysisk-motorisk ferdighet gjennom kroppsøving - et viktig bidrag til elevenes allmenndanning og læring i skolen. Norsk pedagogisk tidsskrift, 2, 155-166. http://www.idunn.no/ts/npt/2013/02/fysiskmotorisk_ferdighet_gjennom_kroppsving_et_viktig_b?highlight=\#highlight

Opheim, V., Grøgaard, J. B., \& Næss, T. (2010). De gamle er eldst? (Vol. 34/2010). Oslo: NIFU STEP.

Rogers, E. M. (2003). Diffusion of innovations. New York: Free Press.

Segberg, U. (2008). Fagdidaktikk i kroppsøving. I E. M. Halvorsen (Red.), Didaktikk for grunnskolen (s. 262-283). Bergen: Fagbokforlaget.

Svingby, G. (1978). Läroplaner som styrmedel för svensk obligatorisk skola: teoretisk analys och ett emperiskt bidrag (Vol. 26). Göteborg: Acta Universitatis Gothoburgensis.

Trudeau, F., \& Shephard, R. (2008). Physical education, school physical activity, school sports and academic performance. International Journal of Behavioral Nutrition and Physical Activity, 5, 10. http://www.ijbnpa.org/content/5/1/10/

Utdanningsdirektoratet (2011).Kunnskapsløftet - om fag-og timefordelingen for grunnopplæringen og tilbudsstrukturen i videregående opplæring. Rundskriv 1-2011. Oslo. http://www.udir.no/Regelverk/Rundskriv/20111/Udir-1-2011-Kunnskapsloftet--fag--og-timefordeling-og-tilbudsstruktur//

Wiborg, Ø. (2011). Elevers prestasjonsutvikling - hvor mye betyr skolen og familien? (Vol. 35/2011). Oslo: NIFU. http://www.nifu.no/files/2012/11/NIFUrapport2011-35.pdf

Yin, R. K. (2009). Case study research. Thousand Oaks, California: Sage. 